\title{
Molecular Detection of Benzimidazole Resistance in Haemonchus contortus Larvae of Goats in Chhattisgarh, India
}

\author{
S. Nath, S. Pal, S. Mandal, S. Jadhao, M. Sankar, S. Muzamil, P.K. Sanyal
}

10.18805/IJAR.B-4532

\begin{abstract}
Background: Benzimidazole resistance is one of the key problem in small ruminant production. A rapid, truthful and responsive system is required for detection benzimidazole resistance so that proper regulatory measure can be applied. Allele specific PCR is one of the tools to understand the mechanism and origin of benzimidazole resistance.

Methods: A total 198 larvae of Haemonchus contortus were isolated from goats of Chhattisgarh region, central India were genotyped by allele specific polymerase chain reaction (AS-PCR). Faecal samples of goats were collected from three Government farms and adjoining field goats and were subjected for faecal culture, separately. DNA of third stage larva was used for nested PCR for amplification of $\beta$ - tubulin gene. Restriction fragment length polymorphism (RFLP) was applied on nested PCR product for species identification with Rsal enzyme. AS-PCR was applied on the nested-PCR product to know the genotypic and allelic frequency.

Result: The nested PCR amplified product showed approximately $820 \mathrm{bp}$ in all cases and PCR-RFLP revealed $462 \mathrm{bp}, 211 \mathrm{bp}$ and $147 \mathrm{bp}$ fragments, which confirmed the species as $H$. Contortus. Frequency of resistant allele (' $r$ ') was $49.7 \%$ and $50.3 \%$ for susceptible allele ('S'). Frequency of homozygous resistant (rr), heterozygous susceptible (rS) and homozygous susceptible (SS) genotype were 33.83 per cent, 31.81 per cent and 34.34 per cent, respectively. The frequency of homozygous resistant (rr) genotype was low $(19.61 \%)$ in field compare to farm $(48.96 \%)$ indicating refugia in field region.
\end{abstract}

Key words: AS-PCR, Benzimidazole resistance, Frequency, Goats, Haemonchus contortus.

\section{INTRODUCTION}

The problem of resistance to anthelmintics has attained clinical and economical importance particularly in trichostrongyloid nematodes of small ruminants and is a serious risk to profitable animal livestock production. There are cases where the prevalence of resistance and the cost of control failure are so high that livestock are in jeopardy. Anthelmintic resistance is outspread in many states of India (Singh and Swarnkar, 2008). Due to widespread emergence of anthelmintic resistance and ubiquitous nature of the organisms presents a difficult challenge in, management/ control of worms (Sanyal, 2014).

It is necessary to monitor the effectiveness of currently available anthelmintics, where there is no resistance and to keep away from further selection of resistance where it has already begun to become illusory (Shalaby, 2013). This is only achievable if there are qualified means for the diagnosis of anthelmintic resistance (AR) available (Pawar et al., 2019). In vivo tests, like the controlled test, which involves necropsy of treated and untreated animals, or the faecal egg count reduction test (FECRT) are exorbitant and laborius. Alternatively, in vitro tests have been established, like the egg hatch assay (EHA) and the larval development tests (LDT) are there. These are quicker, less labor intensive and have been recognized, especially for AR prevalence studies but with lower degree of sensitivity (Singh et al., 2017).

In the present study Allele specific Polymerase Chain Reaction (AS-PCR) is applied to detect benzimidazole resistance in Haemonchus contortus of goats. AS-PCR offer the opportunity to detect the resistance at near the beginning
Department of Veterinary Parasitology, College of Veterinary Science and Animal Husbandary, Anjora, Dau Shri Vasudev Chandrakar Kamdhenu Vishwavidyalaya, Durg-491 001, Chhattisgarh, India.

Corresponding Author: S. Nath, Department of Veterinary Parasitology, College of Veterinary Science and Animal Husbandary, Nanaji Deshmukh Veterinary Science University, Jabalpur-482 001, Madhya Pradesh, India.

Email: subhradal@gmail.com

How to cite this article: Nath, S., Pal, S., Mandal, S., Jadhao, S., Sankar, M., Muzamil, S. and Sanyal, P.K. (2022). Molecular Detection of Benzimidazole Resistance in Haemonchus contortus Larvae of Goats in Chhattisgarh, India. Indian Journal of Animal Research. 56(1): 95-99. DOI: 10.18805/IJAR.B-4532.

Submitted: 19-05-2021 Accepted: 10-08-2021 Online: 08-09-2021

level when only $1 \%$ of parasite populations have become resistant in comparison to conventional methods which are only reliable if more than $25 \%$ worms in a given population are resistant to benzimidazole (Roos et al. 1995). Molecular methods are of great value to understand the origin and mechanism of benzimidazole resistance.

Three single nucleotide polymorphisms (SNPs) in the isotype-1 b-tubulin gene at codon 167, 198 and 200 are accounts for benzimidazole resistance in various nematode species which correlate with benzimidazole resistance (Prichard, 2001; Ghisi et al., 2007; Silvestre and Cabaret, 2002; von Samson Himmelstjerna et al., 2007; Chaudhry et al., 2015; Ramünke et al., 2016). 
There were very few studies on anthelmintic resistance had been done in the above region (Sanyal et al., 2014 and Kumar et al., 2014) but, these studies uses conventional in vitro (Egg hatch test) and in vivo (Faecal egg count reduction test) methods for detection of anthelmintic resistance. Though, AS-PCR is expensive and required trained personal, but it can be applied in for early detection with sensitivity so that proper measures could be taken for sustainable control of gastrointestinal parasites.

\section{MATERIALS AND METHODS Place of study and sample collection}

The proposed work has been taken in Chhattisgarh region, Central India. Chhattisgarh's geographical position is $17^{\circ}$ 46 minutes north to $24^{\circ} 5$ minutes north and $80^{\circ} 15$ minutes east to $84^{\circ} 20$ minutes east with hot and humid climate. These prevailing conditions cause the animals vulnerable for parasitic infection. Faecal samples of goats were collected from three Government Farms Namely Pakaria Goat Farm (Bilaspur), Kawrdha Goat Farm and College Unit Goat Farm, Durg as well as from field goats of the adjoining area of the above three farms.

Benzimidazoles (albendazole/fenbendazole) and ivermectin were alternately used three to four times a year in farm animals, while the frequency of deworming in field goats was less than one or as per the clinical condition of the animal. It was known before the experiment that the chosen animals had not been de-wormed in the previous 3 months. About 10 to 20 grams of faecal samples were collected directly from the rectum of each goats in sterile polybags, labeled and brought to Department of Veterinary Parasitology, College of Veterinary Science and Animal Husbandry, Anjora, Durg (C.G) for further investigation.

In this study 198 infective larvae (L3) of $H$. contortus were genotyped to know the prevalence of genotypic frequencies of homozygous resistance (rr), heterozygous resistance (rS) and homozygous susceptible (SS) for both farm and field population of $H$. contortus larvae. The status of $B Z$ resistance in populations of $H$. contortus larvae collected from goat flocks in semi-intensive and traditional farming in the Chhattisgarh region of Central India by ASPCR was investigated. The above study was carried during the period of June 2018 to June 2019.

\section{Genomic DNA extraction}

DNA extraction from single larvae was done as per the method described earlier by Coles et al. (2006) and Chandra et al. (2015). The positive faecal samples were pooled as per their geographic location of collection and were mixed with activated charcoal powder for faecal culture by petri dish method (Soulsby, 1982). Development of the larvae in the culture was checked regularly, collected and washed 3-4 times with distilled water by centrifuging at $5000 \mathrm{rpm}$ for 1 minute. For exsheathment of larvae, petri dish containing 4 $\mathrm{ml}$ larval suspension (less than 1000 larvae/ml) and $180 \mu \mathrm{l}$ sodium hypochlorite (aqueous solution, about $3.5 \%$ active Chlorine) was added and the suspension was kept for 2030 minutes and checked regularly under microscope for larval exsheathment. Single exsheathed larva was collected under stereo microscope with $2 \mu$ l of suspension by micropipette. The larva was killed by placing it in a PCR tube at $-20^{\circ} \mathrm{C}$ for $20 \mathrm{~min} .5 \mu \mathrm{l}$ of DNA extraction buffer (50 $\mathrm{mM}$ Tris- $\mathrm{HCl}$ ( $\mathrm{pH} 8.0), 10 \mathrm{mM}$ EDTA ( $\mathrm{pH} \mathrm{8.0)}$ ) and $5 \mathrm{mg} / \mathrm{ml}$ proteinase $\mathrm{K}$ ) was added and incubated at $56^{\circ} \mathrm{C}$ for six hours. Inactivation of Proteinase $\mathrm{K}$ was done by incubating lysate at $95^{\circ} \mathrm{C}$ for $20 \mathrm{~min}$. Further, the lysate was centrifuged at $4000 \mathrm{rpm}$ for $2 \mathrm{~min}$ and $5 \mu \mathrm{l}$ of supernatant was used for amplification.

\section{Amplification of $\beta$-tubulin gene and detection of resistance by AS-PCR}

Genomic DNA from third stage exsheathed larvae was used as template for amplification of $\beta$-tubulin isotype I gene as per Silvestre and Humbert (2000) and Coles et al. (2006) with minor modifications. The primary PCR product was used as nested PCR template using primers and reaction conditions as defined by Silvestre and Humbert (2000) and Coles et al. (2006). Consequently, the nested PCR amplicons were digested with the Rsal restriction enzyme (10 U/25 $\mu \mathrm{l}$ reaction) for correct species identification. Allele specific PCR was executed by adding $H$. contortus specific primers in two reactions per larval sample, one for resistant allele and the other for susceptible allele, using the nested PCR product as template for detecting BZ resistance (Coles et al., 2006).

The amplicons were isolated in the TAE (1x) buffer by $2.5 \%$ agarose gel electrophoresis and the resulting fragments were visualized under UV light as a compact fluorescent band of predicted size and recorded by the gel documentation system (Bio-Rad Gel Doc EZ Imager). Chisquare test was applied for statistically analyzing the genotyping of $H$. contortus resistant and susceptible larva (Snedecor and Cochran, 1994).

\section{RESULTS AND DISCUSSION}

The Nested PCR amplified a product of approximately $820 \mathrm{bp}$ in all cases (Fig 1). The Rsal digested amplicons showed major fragments around $462 \mathrm{bp}, 211 \mathrm{bp}$ and $147 \mathrm{bp}$, which proved the species as $H$. contortus (Fig 2 ).

The size of the specific bands was around $603 \mathrm{bp}$ for susceptible allele-specific gene while resistant allele-specific gene showed product size of $222 \mathrm{bp}$ and another non-allele specific gene showed band size around 774 bp (Fig 3 and Fig 4). The results of larval genotyping using AS-PCR from various regions of Chhattisgarh were presented in Table 1. The AS-PCR results showed the overall prevalence of resistant allele ' $r$ ' $49.7 \%$ and susceptible allele 'S' $50.3 \%$. The genotypic frequency of homozygous resistant (rr), heterozygous susceptible (rS) and homozygous susceptible (SS) were $33.83 \%, 31.81 \%$ and $34.34 \%$, respectively. The samples from farm regions indicated that $12.5-66.67 \%$ of 


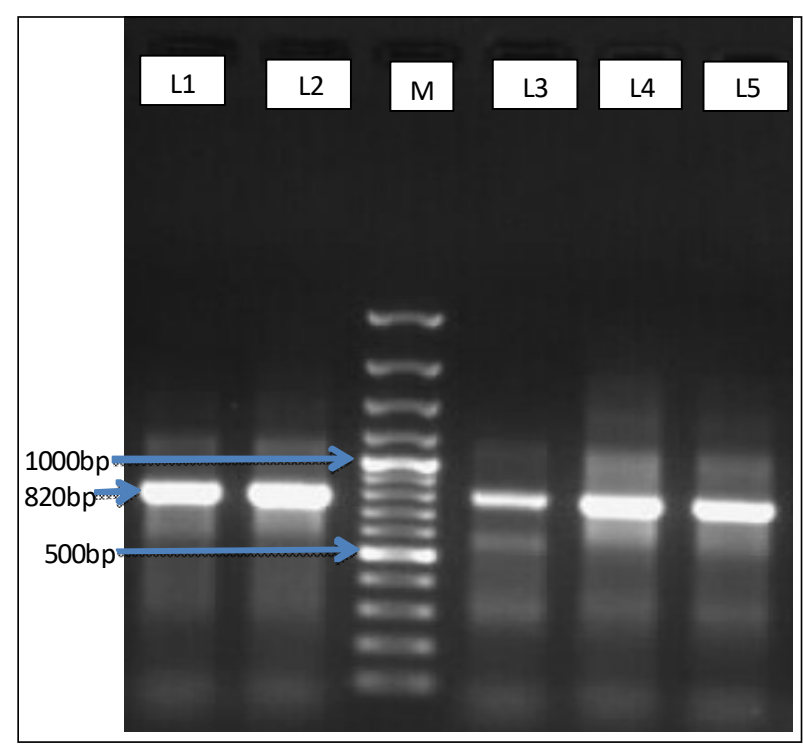

Fig 1: Nested PCR product at 820 bp showing amplification of $\beta$-tubulin gene Lane 1100 bp plus DNA marker.

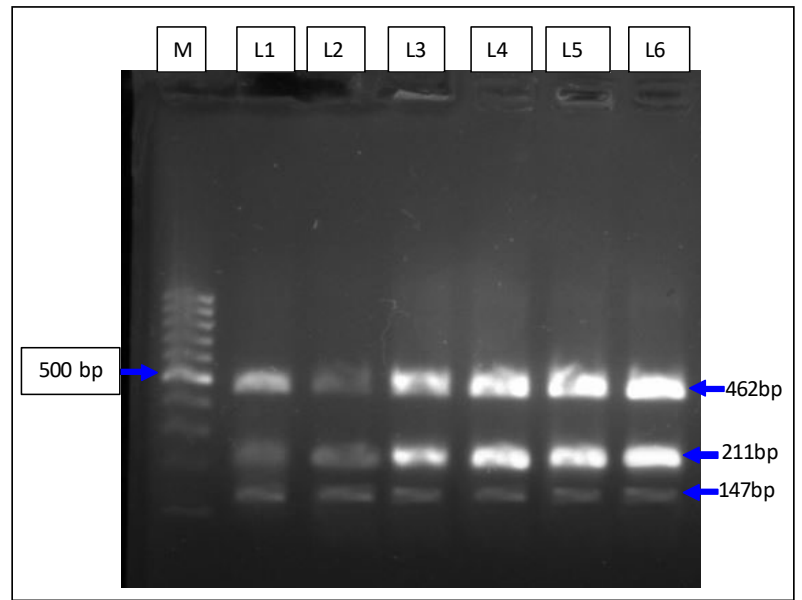

Fig 2: RFLP of larvae collected from different farm and field showing 3 bands at $462 \mathrm{bp}, 211 \mathrm{bp}$ and $147 \mathrm{bp}$ confirming Haemonchus contortus Lane 1100 bp plus DNA marker (M) Lane 2-7 (Larvae 1-6).
H. contortus larvae were homozygous resistant ( $\mathrm{rr}, \mathrm{TTC}$ ), $16.67-41.67 \%$ homozygous susceptible (SS, TAC) and $16.67-45.83 \%$ heterozygous susceptible (rS, TTC/TAC).

In Durg, College Unit Goat farm, the genotypic frequency of larvae with regard to homozygous resistant (rr) was substantially greater $(P<0.01)$. In the field region, the overall frequency of homozygous resistant (rr, TTC) was $6.67-25 \%, 33.33-41.67 \%$ heterozygous susceptible (rS, TTC/TAC) and 33.33-60\% homozygous susceptible (SS, TAC). The genotypic frequency of homozygous susceptible (SS) $H$. contortus larvae was significantly higher $(P<0.01)$ in Bilaspur field region.

In farms, where the treatment frequency was higher (3-4 times in a year) showed higher degree of resistance revealing $48.96 \%$ of homozygous resistance genotype ( $\mathrm{rr}$ ) and $60.96 \%$ of resistant allele $(r)$ frequency. Whereas in field area the frequency of resistant individual ( $\mathrm{rr}$ ) was 19.6\% which is significantly lower $(P<0.01)$ than susceptible individual (SS). Among farm animals, $H$. contortus infecting goats of College Unit Farm, Durg region revealed highest $(66.67 \%)$ genotypic frequency of homozygous resistant (rr) genotype and its corresponding field area, showing $25 \%$ genotypic frequency of homozygous resistant ( $r r)$ in the population of $H$. contortus. However, due to proper anthelmintic management and other mitigation strategies like pasture rotation etc. in Pakaria Goat Farm, Bilaspur there was lowest frequency $(12.5 \%)$ of homozygous resistance (rr) genotype among all the farms. The corresponding field region showed lowest degree $(6.67 \%)$ of resistance.

As the animals of field area were in the close proximity to the farm goats chances of using the same grazing land was higher thereby getting resistant nematodes. The results indicated that benzimidazole resistance is reached alarming level in farms and emerging in field condition. These findings confirmed that there was an impact of status of resistance of the farm area on field area and there is dissemination of the phenomenon of resistance from farm to field.

Many workers in India and abroad had used AS-PCR based genotyping for the detection of $B Z$ resistance in strongyles of small ruminants, cattle and equines as this

Table 1: Genotyping of larvae of Haemonchus contortus in different farm and field region.

\begin{tabular}{|c|c|c|c|c|c|c|c|}
\hline \multirow[b]{2}{*}{ Location } & \multirow{2}{*}{$\begin{array}{c}\text { No. of } \\
\text { L3 } \\
\text { larvae }\end{array}$} & \multirow{2}{*}{$\begin{array}{c}\chi^{2} \\
\text { value }\end{array}$} & \multicolumn{3}{|c|}{ Genotypic frequency } & \multicolumn{2}{|c|}{ Alleleic frequency } \\
\hline & & & $\begin{array}{l}\text { Homozygous } \\
\text { resistant rr }\end{array}$ & $\begin{array}{l}\text { Heterozygous } \\
\text { susceptible rS }\end{array}$ & $\begin{array}{l}\text { Homozygous } \\
\text { susceptible SS }\end{array}$ & $\begin{array}{l}\text { Resistant } \\
\text { allele }\end{array}$ & $\begin{array}{c}\text { Susceptible } \\
\text { allele }\end{array}$ \\
\hline Durg, College Unit Farm & 48 & $33.38^{* *}$ & $66.67 \%(32)$ & $16.67 \%(8)$ & $16.67 \%(8)$ & $75.0 \%$ & $25.0 \%$ \\
\hline Bilaspur Farm & 24 & $7.125^{\mathrm{NS}}$ & $12.50 \%(3)$ & $45.83 \%(11)$ & $41.67 \%(10)$ & $35.0 \%$ & $65.0 \%$ \\
\hline Kawardha Farm & 24 & $4.875^{\mathrm{NS}}$ & $50 \%(12)$ & $20.83 \%(5)$ & $29.17 \%(7)$ & $61.0 \%$ & $39.0 \%$ \\
\hline Total (Farm Unit) & 96 & $15.84^{* *}$ & $48.96 \%(47)$ & $25 \%(24)$ & $26.04 \%(25)$ & $61.46 \%$ & $37.5 \%$ \\
\hline Durg, Field Tegion & 48 & $2.438^{\mathrm{NS}}$ & $25 \%(12)$ & $39.58 \%(19)$ & $35.42 \%(17)$ & $45.0 \%$ & $55.0 \%$ \\
\hline Bilaspur Field Region & 30 & $19.2^{* *}$ & $6.67 \%(2)$ & $33.33 \%(10)$ & $60 \%(18)$ & $23.0 \%$ & $77.0 \%$ \\
\hline Kawardha Field Region & 24 & $1.5^{\mathrm{NS}}$ & $25 \%(6)$ & $41.67 \%(10)$ & $33.33 \%(8)$ & $46.0 \%$ & $54.0 \%$ \\
\hline Total (Field Region) & 102 & $13.32^{* *}$ & $19.61 \%(20)$ & $38.23 \%(39)$ & $42.16 \%(43)$ & $38.73 \%$ & $61.27 \%$ \\
\hline Total & 198 & $0.85^{\mathrm{NS}}$ & $33.83 \%(67)$ & $31.81 \%(63)$ & $34.34 \%(68)$ & $49.7 \%$ & $50.3 \%$ \\
\hline
\end{tabular}

${ }^{* *}$ Values indicate significance at $\mathrm{P}<0.01$. NS; Non-significant. 


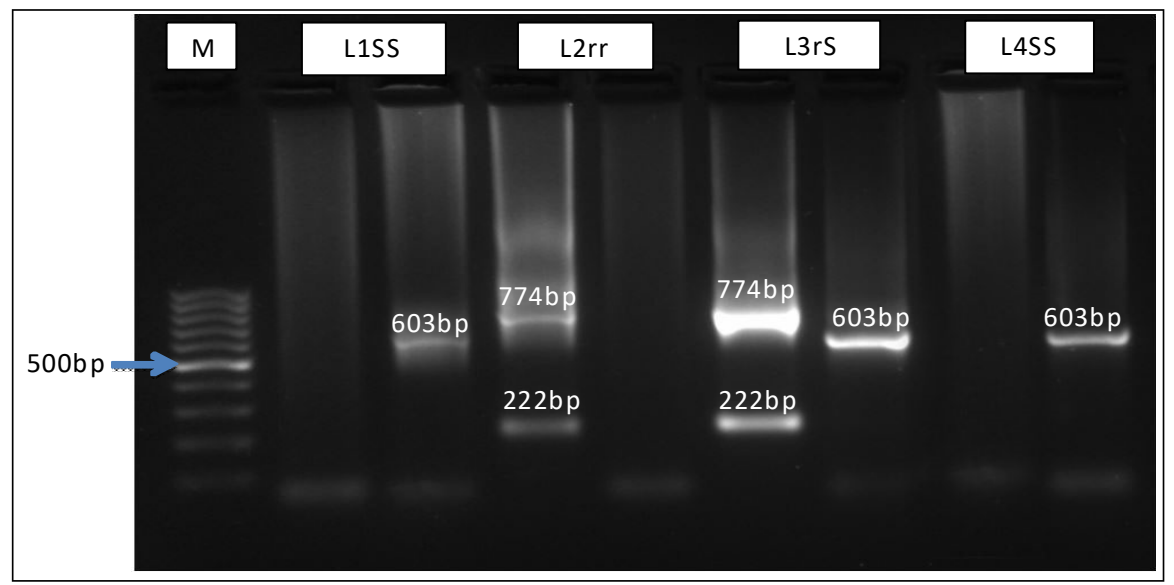

Fig 3: Genotyping of Haemonchus contortus for benzimidazole resistance of representative farm sample. Lane 1, 100 bp plus DNA marker (M) Lane 2-9: Larvae (4).

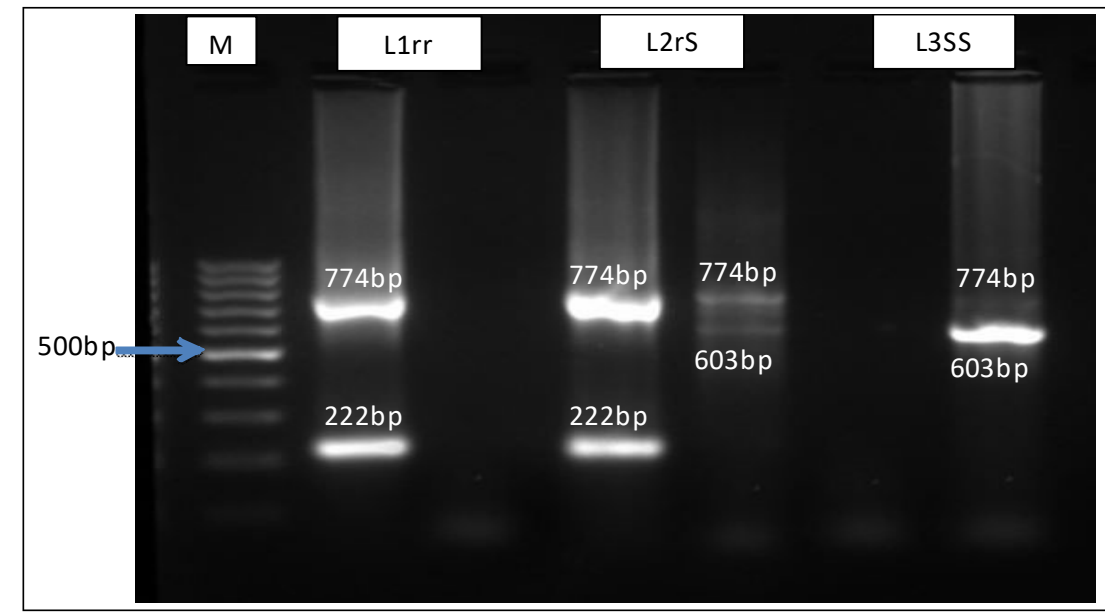

Fig 4: Genotyping of Haemonchus contortus for benzimidazole resistance of representative field sample.

Lane 1, 100 bp plus DNA marker (M) Lane 2-7: Larvae (3).

test produced unerring results (Silvestre and Humbert, 2000; Winterrowd et al., 2003; von Samson-Himmelstjerna et al., 2007; Chandra et al., 2015; Dixit et al., 2017; Singh et al., 2019).

Unlike our results Singh et al. (2019) in the study of genotyping of $H$. contortus larvae collected from sheep from six districts of Punjab observed higher level of resistance showing overall genotypic frequency of $49.28 \%$ for homozygous resistant $\mathrm{rr}, 46.37 \%$ homozygous susceptible SS and heterozygous susceptible rS genotype showing low frequency of $3.62 \%$. The allelic frequencies were 0.72 and 0.28 for resistant and susceptible allele respectively. Much the same results were discerned by Dixit et al. (2017) where they found $62 \%$ of $H$. contortus larvae were homozygous resistant (rr), $14 \%$ homozygous susceptible (SS) and $24 \%$ heterozygous susceptible (rS). The frequency of resistant allele was significantly $(P<0.01)$ higher $(74 \%)$ than susceptible allele (S) (26\%). Chandra et al. (2015) in the study from different regions of Uttar Pradesh detected 55$85 \%$ of $H$. contortus as homozygous resistant rr, $10-21 \%$ homozygous susceptible SS and 5-24\% heterozygous susceptible rS. The allelic frequencies were $67-87.5 \%$ for resistant and $12.5-33 \%$ for susceptible.

Similar to our findings, significantly lower $(P<0.005)$ overall frequency of resistant (rr) (17\%) genotype than homozygous susceptible (SS) $61 \% \mathrm{H}$. contortus male was reported from two agro-climatic zones, viz. Tarai and Hill of Uttarakhand, India by Pandey and Vatsya (2013). Overall, prevalence of benzimidazole resistant allele $(r)$ was significantly $(P<0.005)$ lower $(28 \%)$ than benzimidazole susceptible allele (S) (72\%).

The present study only consider the F200Y mutation in the $\beta$-tubulin gene which could be identified by the ASPCR technique, but it cannot recognize other mutations that could be responsible for the production of resistance to benzimidazole viz. E198A, F167Y etc (Prichard, 2001; Ghisi et al., 2007). If one of these polymorphisms is present in the $H$. contortus populations under study, then the degree of resistance could be much more in the areas under study. 


\section{CONCLUSION}

In the present study, a moderate frequency of homozygous resistant $33.83 \%$, (rr) and heterozygous genotypes $31.81 \%$ (rS) suggests that the resistance is establishing in this area at a quicker rate. Anthelmintic resistance is now accepted as inevitable phenomenon and the genes or alleles deliberating resistance to anthelmintics are conceived to be in perseverance in unselected worm population. Therefore, immediate regulatory measure must be given for anthelmintic administration so that spreading of resistant population is minimized.

Consequently, for all anthelmintics that have been made to date, it appears that the evolution of anthelmintic resistance is an inescapable consequence of their use but its development can be delayed. The felicitous measures like targeted selective treatment by employing FAMACHA need to be enforced urgently to disparage the dissemination of anthelmintic resistance.

\section{ACKNOWLEDGEMENT}

Author is thankful to Dean, College of Veterinary Science and Animal Husbandry, Anjora, DVCKV, Durg (C.G) for providing necessary facilities to carry out the present work successfully.

\section{REFERENCES}

Chandra, S., Prasad, A., Yadav, N., Latchumikanthan, A., Rakesh, R.L., Praveen, K., Khobra, V., Subramani, K.V., Misri, J. and Sankar, M. (2015). Status of benzimidazole resistance in Haemonchus contortus of goats from different geographic regions of Uttar Pradesh, India. Veterinary Parasotology. 208(3-4): 263-267.

Chaudhry, U., Redman, E.M., Raman, M. and Gilleard, J.S. (2015). Genetic evidence for the spread of a benzimidazole resistance mutation across southern India from a single origin in the parasitic nematode Haemonchus contortus. International Journal for Parasitology. 45: 721-728.

Coles, G.C., Jackson, F., Pomroy, W.E., Prichard, R.K., von SamsonHimmelstjerna, G., Silvestre, A., Taylor, M.A. and Vercruysse, J. (2006). The detection of anthelmintic resistance in nematodes of veterinary importance. Veterinary Parasitology. 136: 167-185.

Dixit, A.K., Das, G., Dixit, P., Singh, A.P., Kumbhakar, N.K., Sankar, M. and Sharma, R.L. (2017). An assessment of benzimidazole resistance against caprine nematodes in Central India. Tropical Animal Health. 49(7): 1471-1478.

Ghisi, M., Kaminsky, R. and Maser, P. (2007). Phenotyping and genotyping of Haemonchus contortus isolates reveals a new putative candidate mutation for benzimidazole resistance in nematodes. Veterinary Parasitology. 144: 313-320.

Kumar, D., Sanyal, P.K., Wahane, Namrata, Pal, S., Bisen, S. and Baghel, K.R. (2014). Evidence of anthelmintic resistance in ruminants of Jashpur district of Chhattisgarh. Indian Journal of Small Ruminant. 20(20): 62-65.

Pandey, N. and Vatsya, S. (2013). Detection of benzimidazole resistance in Haemonchus contortus populations collected from sheep of Uttarakhand using allele specific PCR assay. Indian Journal of Animal Science. 83(1): 24-26.
Pawar, P.D., Singla, L.D., Kaur, P. Bal, M.S. and Javed, M. (2019). Evaluation and correlation of multiple anthelmintic resistance to gastrointestinal nematodes using different faecal egg count reduction methods in small ruminants of Punjab, India. Acta Parasitologica. 64: 456-463.

Prichard, R.K. (2001). Genetic variability following selection of Haemonchus contortus with anthelmintics. Trends in Parasitology. 17: 445-453.

Ramünke, S., Melville, L., Rinaldi, L., Hertzberg, H., de Waal, T., von Samson-Himmelstjerna, G., et al. (2016). Benzimidazole resistance survey for Haemonchus, Teladorsagia and Trichostrongylus in three European countries using pyrosequencing including the development of new assays for Trichostrongylus. The International Journal for Parasitology-Drugs and Drug Resistance. 6(3): 230-240.

Roos, M.H., Kwa, M.S.G. and Grant, W.N. (1995). New genetic and practical implications of selection for anthemintic resistance in parasitic nematodes. Parasitology Today. 11: 148-150.

Sanyal, P.K., Rawte, D., Kerketta, A., E., Pal, S., Baghel, K.R. and Bisen, S. (2014). Emergence of anthelmintic resistance in ruminants in Chhattisgarh. Journal of Veterinary Parasitology. 28(1): 40-43.

Shalaby, H.A. (2013). Anthelmintics resistance; How to overcome it? Iranian Journal of Parasitology 8(1): 18-32.

Silvestre, A. and Cabaret, J. (2002). Mutation in position 167 of isotype 1 beta-tubulin gene of Trichostrongylid nematodes: Role in benzimidazole resistance? Molecular and Biochemical Parasitology. 120: 297-300.

Silvestre, A. and Humbert, J.F. (2000). A molecular tool for species identification and benzimidazole resistance diagnosis in larval communities of small ruminant parasites. Experimental Parasitology. 95: 271-276.

Singh, E., Kaur, P., Singla, L.D., Sankar,M., Bal, M.S. (2019). Molecular detection of benzimidazole resistance in Haemonchus contortus of sheep in Punjab. Indian Journal of Animal Science. 89(12): 1322-1326.

Singh, R., Bal, M.S., Singla, L.D. and Kaur, P. (2017). Detection of anthelmintic resistance in sheep and goat against fenbendazole by faecal egg count reduction test. Journal of Parasitic Diseases. 41(2): 463-466.

Singh, D. and Swarnkar, C.P. (2008). Role of refugia in management of anthelmintic resistance in nematodes of small ruminants: A review. Indian Journal of Small Ruminant. 14: $141-180$

Snedecor, G.W. and Cochran, W.G. (1994). Statistical Methods, $8^{\text {th }}$ Edn., Oxford and IBH Publishing Co., New Delhi.

Soulsby, E.J.L. (1982). Helminths, Arthopods and Protozoa of Domisticated Animals. $7^{\text {th }}$ Edn. ELBS and Bailliere, Tindall, Casell Ltd., London: 773-774.

von Samson-Himmelstjerna, G., Blackhall, W.J., McCarthy, J.S. and Skuce, P.J. (2007). Single nucleotide polymorphism (SNP) markers for benzimidazole resistance in veterinary nematodes. Parasitology 134: 1077-1086.

Winterrowd, C.A., Pomroy, W.E., Sangster, N.C., Johnson, S.S. and Geary, T.G. (2003). Benzimidazole-resistant betatubulin alleles in a population of parasitic nematodes (Cooperia oncophora) of cattle. Veterinary Parasitology. 117(3): 161-172. 